ÉGYPTE

monde arabe

\section{Égypte/Monde arabe}

$34 \mid 1998$

Droits d'Égypte : histoire et sociologie

\title{
The infatuated Greek : Social and Legal Boundaries in Nineteenth-century Egypt
}

\section{Rudolph Peters}

\section{(2) OpenEdition}

1 Journals

Édition électronique

URL : https://journals.openedition.org/ema/1490

DOI : 10.4000/ema. 1490

ISSN : 2090-7273

Éditeur

CEDEJ - Centre d'études et de documentation économiques juridiques et sociales

Édition imprimée

Date de publication : 31 décembre 1998

Pagination : 53-66

ISSN : 1110-5097

\section{Référence électronique}

Rudolph Peters, «The infatuated Greek : Social and Legal Boundaries in Nineteenth-century Egypt », Égypte/Monde arabe [En ligne], 34 | 1998, mis en ligne le 08 juillet 2008, consulté le 07 juillet 2022. URL : http://journals.openedition.org/ema/1490; DOI : https://doi.org/10.4000/ema.1490

Ce document a été généré automatiquement le 7 juillet 2022.

Tous droits réservés 


\title{
The infatuated Greek : Social and Legal Boundaries in Nineteenth- century Egypt
}

\author{
Rudolph Peters
}

1 Society is made up of a multitude of social groups sharing common characteristics such as level of wealth, origin, age and gender. Some of these groups may have a special legal status, assigning to their members special rights and obligations. In this case the law gives a precise definition of the group and draws a clear cut boundary between this and the other groups. Nowadays, under the influence of the doctrine of equality before the law, the number of groups that have a legal position distinct from other categories has decreased. What remains is, for instance, the distinction between nationals and aliens. In pre-modern societies, however, there were more categories and some of these existed until quite recently, e.g. the difference in legal status between men and women. Belonging to such a legally relevant group implied that one had special privileges, but also that one had to behave in a certain manner. The law would also regulate to what extent and how it was allowed to cross such boundaries by abandoning one group and entering another. Infringement of the rules connected with one's status would entail legal sanctions.

2 The case presented here is one where the dramatis personae broke the rules connected with their status. It was a criminal case tried in Egypt in the 1860s. Through it I intend to show how the Egyptian legal system, as it existed in the period before the British occupation, enforced the rules connected with the legal status of certain groups in society.

\section{The legal and judicial setting of the case}

The case was tried by Egyptian state courts (as distinguished from the Islamic court of the qâdî) that were part of a judiciary which had evolved since the time of Mehmed 'Alî. It consisted of councils that were part of the executive and specialized in the trial of 
criminal cases and in dealing with administrative conflicts. These councils were staffed not by professional jurists, but by officials serving for some time in these councils as a normal part of their administrative career. The sentences of these councils, just like administrative decisions, were the result of examination and review of the case in several instances, the last one being the decision of the majlis al-ahkâm, the highest judicial and legislative council. However, in capital or other important cases the sentence of the majlis al-ahkâm had to be approved by the Khedive. The present case was first heard and prepared by the Police Council (majlis al-dabtiyya). Then it was looked into by the Cairo Council, whose decision was subsequently reviewed by the majlis al-ahkâm. The proceedings before these councils were juridically not very sophisticated. The defendant had no right to legal assistance and appeared during the session only if it was necessary for the investigation, for example, when one of the councilors wanted to interrogate him.

The criminal code applied in this case was the Imperial Code (al-qânûnnâme al-sultânî or al-qânûn al-humâyûnî) introduced in $1852 .{ }^{1}$ This was essentially the Ottoman Penal Code of 1851. As a consequence of the Ottoman policy of strengthening its control over the autonomous parts of the Empire, the Sultan had required that this code take effect also in Egypt. ${ }^{2}$ The outcome of the ensuing negotiations between the Khedive 'Abbâs and the Porte was that in $1852^{3}$ this code was introduced in Egypt with some modifications and additions. The Ottoman Penal Code consisted of three chapters. To these, two others were added, containing provisions from previous Egyptian codes. Criminal legislation did not abolish the application of the sharî'a in criminal matters. The qâdî alsoheard such cases, but dealt with them from a different angle, namely as an adjudication of private claims, generally financial (i.e. damages), but sometimes also punitive (e.g. retribution in cases of willful killing or wounding). In fact, these codes fit in the framework of Islamic law, as they must be regarded as codified ta'zîr, which was also the basis of Ottoman qânûn. Two sections (Chapter Two, Sections One and Two) of the Imperial Code referred to in the record clearly evidence this state of affairs since they are entirely in harmony with the prescriptions of the shari'a. Section One lays down that, in cases in which a person's honor is injured (hitk al-'ird), the appropriate shari'a punishments must be imposed, whereas Section Two stipulates that such acts, if they are not punishable under the strict prescriptions of the shari' $a$ can be punished on the strength of $t a^{\prime} z \hat{i}$, the general power of the authorities to punish sinful behavior.

\section{Legal personality in classical Islamic law}

5 In nineteenth-century Egypt, there was no legal doctrine or branch of jurisprudence based on enacted law and separate from Islamic jurisprudence. The application of statute laws was informed by the shari'a. Since these laws as a rule did not define general legal concepts, such as criminal responsibility, causality and so forth, they were adopted from Islamic jurisprudence. The investigation will now discuss the concept of legal capacity in classical Islamic law in order to clarify the legal boundaries that existed between different categories of legal persons. Legal personality in Islamic law is defined by three dichotomies, creating legal boundaries between dominant and nondominant groups: Muslims versus non-Muslims; men versus women; free persons versus slaves. 
6 Every person's legal capacity is a function of these three dichotomies and therefore there are eight categories of persons. The differences in legal capacity extend to most spheres of the law. The fullest legal capacity is that of a Muslim free male. All others have fewer rights. The clearest illustration of the existence of these categories is the differentiation in bloodmoney which must be paid if a person is killed. The highest amount must be paid for a free Muslim male, whereas no blooodmoney is due if a nonMuslim from outside the Abode of Islam (harbî) is killed. The latter category of persons lack almost any form of legal personality. Their lives (except the lives of women and children), like their properties, are not protected by the law. Non-Muslims living legitimately on Islamic territory do enjoy protection of life, property and freedom. However, their legal capacity is restricted by the fact that they are incapable of performing legal acts or entering into legal relationships implying some form of authority over Muslims. Therefore, they cannot hold public offices, be guardians over Muslim minors or possess Muslim slaves. Moreover, non-Muslim men may not marry Muslim women, whereas there is no legal impediment for Muslim men to marry Christian and Jewish women. In view of the notion of marriage in Islamic law, with the husband having matrimonial authority over his wife, this is a logical rule. In order to emphasize the divide between Muslims and non-Muslims, the law lays down that protected non-Muslims must distinguish themselves in their attire from the Muslims and imposes certain restrictions on their social life aimed at making manifest their subject position. These restrictions affected, for example, their ways of transport-they were not allowed to mount horses-and their houses, which had to be lower than neighboring houses in which Muslims lived.

7 The distinction between free persons and slaves is of a different nature. Slaves are both property and persons. Their lives are protected, but they lack the capacity to fully own property or to have legal authority over free persons. The limitations of their legal capacity are a function of their owners' property rights over them. And like nonMuslims, they are not allowed to have legal authority over free persons.

8 Finally, the distinction based on gender will not be elaborated here as the legal status of women in Islamic law is well-known. Although in financial matters women have the same rights as men, this is not the case in other fields of the law such as family law, succession, procedure and public law, where women are considered to have a status inferior to men. Furthermore, there is a body of rules governing the relations, social and otherwise, between the sexes.

9 The nature of these legal boundaries is very different. The gender boundary is related to a person's innate physical characteristics. As a rule, these are evident. In exceptional cases, however, the physical signs are ambiguous and most classical legal textbooks include a chapter on the hermaphrodite in which the jurists go to great lengths to find criteria for classifying them in either category. The legal significance of this boundary is emphasized by the strong sanctions attached to forms of conduct ignoring or obscuring gender categories such as homosexuality and transvestism (takhnith). Recently, Islamic jurists in Egypt had to address the question of sex change operations. Although the Mufti of the Republic, Sayyid Tantâwî, held that such an operation is permissible, being a form of treatment meant to make manifest the gender which a person « really" possesses, the case was widely debated and the fatwâ gave rise to fierce opposition from persons who regarded it as an unlawful and arbitrary blurring of gender boundaries. ${ }^{4}$ 

exercised by one person over another. Here the crossing of the boundaries is thinkable. Islamic law permits it only in two cases : a non-Muslim may convert to Islam and a slave may be freed. Crossing them in the opposite direction is legally impossible. A Muslim abjuring his religion does not acquire the status of a protected non-Muslim, but loses his legal capacity and is put to death or (in the case of the female apostate under Hanafite and Shi'ite law) excluded from society by perpetual imprisonment. Similarly a free person, Muslim or protected non-Muslim, may not be enslaved.

The following case deals with the position of non-Muslims in Muslim society. The main characters of the drama transgressed the rules concerning the divide between Muslims and Christians.

\section{The case}

On 9 August $^{5}, 1863$ (4 rabî' I, 1280), a certain Sulaymân Shahâta from Alexandria notified the Cairo police that his sister, a girl named Sitêta, had been seduced by a dhimmî, an Ottoman subject of Greek ethnicity, named Filibû Wânîs (Filippo Yoannis ?), who used to live in the tenement house where their father worked as doorman, and that on 3 June, 1863 (15 dhû al-hijja, 1279), she had fled to Cairo, to where the Greek had moved earlier. He requested that the police trace her and her seducer. The police immediately began to work on the case and on the same day they found the couple living in an apartment belonging to a certain Shîmî al-Hallâq, located in the hâra of the Darb alJadîd in Muskî. They were then taken to the police station and interrogated. They did not deny the essentials of the complaint. The girl (and probably the man as well, although there is no specific mention of it) were taken into custody, where they were detained awaiting trial.

The girl's version of the events included some elements meant to alleviate her guilt : a Greek couple, Mikhali Aglanios and his wife Fanîl (?), a washer-woman, had incited her to leave her home and stay with them. She had stayed with them for three days before they put her on a train to Cairo. Filippo had met her at the station and taken her to his home. There he had plied her with liquor and slept with her. When she woke up, she found that she had lost her virginity. In Filippo's statement, it is the girl who took the initiative. She had written a letter complaining about her hardship and suggesting that she come to him, but he had not sent an answer. On 28 May (yawm al-waqfa, i.e. dhû alhijja 9), he had gone to Alexandria on business and stayed there two nights. Eight days later, Mikhali visited him and gave him the letter from the girl. In it she informed him that she had left her parents seven days earlier and could not return to them. She asked him to let her come to Cairo or else she would drown herself in the sea. Thereupon, he told Mikhali to put her on the train to Cairo, which he did upon his return to Alexandria. Filippo picked her up at the station, and took her home, pretending that she worked for him. When he slept with her, she did not bleed, although she had claimed to be a virgin. His only motive to let her come to Cairo was his fear that she would commit suicide. He finally declared that he had become a Muslim and was willing to marry the girl.

When the police tried to interrogate Mikhali and his wife, it turned out that they had Greek nationality. The police, in turn, applied to the Greek consulate requesting to question Mikhali and his wife. The answer from the consulate did not arrive until

Égypte/Monde arabe, 34 | 1998 
nearly eight months later (4 May, 1864/27 dhû al-qa'da, 1280), after the intervention of the Ministry of Foreign Affairs. They were then questioned by the Alexandria Police, but the result was disappointing: Mikhali and his wife acknowledged that they knew the girl, as she had occasionally delivered laundry to them, but they said they knew nothing of the case. Later, both Filippo and Sitêta admitted that they had made up the story of the Greek couple's incitement and assistance by way of mitigation.

After the interrogation of the couple, police investigations focused on two issues: Filippo's antecedents and the circumstances under which he had rented the apartment in Cairo. Concerning Filippo's background, they found out that he was a tobacco merchant (dakhâkhinî), who had nearly gone bankrupt. His debts amounted to some 64000 piasters. However, he had paid off about 58000 piasters and his creditors had accepted bonds for the remaining debts. The interest of the police in his financial affairs ended here and they stopped the investigations in this direction. In order to get information on how Filippo rented his apartment, they summonned the shaykh al-hâra (head of the district) a man called Îsa al-Habbâk. His questioning focused on why he had not demanded a guarantor (daman) from Filippo when he came to live in the hâra. The shaykh stated that Filippo had told him he was married but that his wife was still in Alexandria and would join him later. Furthermore, he declared that he had asked Filippo several times to bring a guarantor, and that he always promised to bring one. When Filippo had reached an agreement with the landlord, he let him have the keys even though Filippo had not yet brought a guarantor, because he knew that Filippo was a well-known merchant. Two witnesses confirmed that the shaykh had repeatedly reminded Filippo to bring a guarantor. The shayktis antecedents were examined and turned out to be not entirely unblemished. Some five years earlier (in safar 1275, September/October 1858), he had been dismissed from his office after complaints that he had evicted shopkeepers and tenants in order to line his purse. However, after witnesses had testified that he was an honest man, he had been reinstated some months later, in March 1859.

After the investigation, the case was submitted to the Police Council (majlis al-dabtiyya) for trial in the first instance. The council considered that there was sufficient circumstantial evidence indicating that Filippo had incited the girl to leave her parents and come to him and that, according to his own confession, he had violated her honor by deflowering her. As to his conversion, the council held that it did not absolve him from his punishment. The council asked why his conversion took place at this particular moment, since if it had been prompted by sincere belief, he could have " obtained this honor" at any time before. Considering further that inciting a girl to leave her parents and violating her honor are very serious offenses, the council proposed to sentence Filippo to one year light forced labor (« lowly jobs in factories or other activities ») on the strength of Chapter Two, Sections Two and Six of the Penal Code. (For the texts of these Sections, see the Appendix). The offenses listed in these sections are the injuring of a person's honor and abduction of a girl. Since the girl willingly participated in these acts and therefore injured the honor of her family, the sentence proposed for her was eight months in the women's prison (iplikkhâne, the spinning mill in Bûlâq) on the strength of Chapter Two, Section Two, with deduction of the time spent in custody awaiting trial. With regard to the Greek couple, who allegedly helped the girl to leave her parents, the council could not give a verdict since they had not yet been questioned. Finally the council looked into the matter of whether the shaykh al-hâra deserved to be punished. Considering that he allowed Filippo to live in 
the hâra without having brought a guarantor, and knowing that Filippo was staying there alone, this factor facilitating the subsequent events, the council, on the strength of Chapter Five Section Seven, sentenced 'îsâ al-Habbâk to be permanently removed from the office of shaykh al-hâra, taking into account the fact that he had been dismissed previously.

By the end of March or early April $1864^{6}$ the Cairo Council dealt with the case. The Council first looked into the shari'a aspects of the case. ${ }^{7}$ Sitêta was asked whether she wanted to sue Filippo before the sharî'a court for damages resulting from her defloration. She declared that she had no claim against him. The council's mufti concluded that in view of the girl's statement, Filippo was not liable to Sitêta for damages. Having dealt with the civil aspects, the Council proceeded with the trial. Like the Police Council, they considered the circumstantial evidence sufficient to establish Filippo's guilt in making the girl leave her family with the aim of violating her honor. However, taking into account that Filippo was not from Egypt, the Council, on the strength of Chapter Two, Sections One and Two, sentenced him to be deported to his country of origin. The sentences of the other defendants were found to be appropriate. When, in early May of that year, a letter arrived from the Alexandria Police with a report about the questioning of the Greek couple, who had allegedly helped the girl in leaving her family, the Council decided that they were innocent.

18 Finally, on 12 June, 1864 ( 7 muharram, 1281) the case was examined by the majlis alahkâm. The majlis considered that in view of the seriousness of the offenses, the punishments imposed by the Cairo Council were too light and sentenced Filippo to one year of hard labor in the Alexandria Dockyards, and Sitêta to one year in the women's prison, both with deduction of the time spent in custody. The shaykh al-hâra was sentenced to two months light labor, in addition to his dismissal.

\section{Analysis}

19 The case concerns an illicit love affair between a young girl, Sitêta, and a Greek merchant, Filippo, who knew each other because he lived in the tenement house in Alexandria where her father was the bawwâb, or doorman. Now, under Islamic law, sexual intercourse is permitted only within two legal relationships: marriage and concubinage, i.e. a man's right of ownership over a slave woman. Otherwise, sexual intercourse is unlawful and may entail either the application of the hadd penalty for zinâ (punishment limitatively acknowledged by the sharîa for fornication) for both partners, or a liability of the man for damages, resulting from illegal intercourse, to be paid to the woman. The damages amount to her proper bride-price, i.e. her « market value on the marriage market, » in other words the bride-price a woman of her age, social status, beauty and so forth, would normally receive when she marries. In addition, the man or both parties may be punished by ta'zîr, the general power of the $q a \hat{d} \hat{\imath}$ orthe executive to punish persons for sinful behavior. At the time of this case, Islamic law was still the law of the land in Egypt. The Penal Code enforced at that time, must be regarded as codified ta'zir. As is clear from the proceedings, Islamic law was not superseded by the Criminal Code, but existed alongside with it. During the trial by the Cairo Council, Sitêta was asked whether she had any financial claim against Filippo, which refers to a claim for damages according to the sharî'a. 

being unmarried and lower class, was in her late teens. Filippo, who seems to have been a well-established merchant in view of the amount of his debts and what he had discharged, may have been in his thirties or forties. Interestingly, the record does not mention whether or not Filippo was married. If he was, this might explain his reluctance in bringing a guarantor after he had rented the apartment in Cairo. It is not plausible that a merchant with his background, a member of the large Greek community, could not have found a person in Cairo willing to vouch for him. His reluctance must have been the result of his apprehension that Cairo acquaintances would discover what he was up to. The court did not mention his marital status, although it is likely that he was married, because from a Muslim viewpoint, this was irrelevant. The affair was scandalous in Muslim eyes not because Filippo may have been married, but first and foremost because these sexual relations were unlawful, as they took place outside wedlock or legal concubinage. of his way to provide an opportunity to consummate their love. From the case, it is clear that renting an apartment was not a simple affair for a single man and that it was difficult to do so anonymously. This was evidently true even for quarters inhabited mainly by foreigners, such as the Muskî area, where Filippo found his lodging. He must have known this but was still prepared to run a great risk. On the part of the girl, there was first the willingness to leave her family for her lover and secondly her refusal to sue Filippo for damages, although there must have been pressure on her to do so from relatives.

This leads to the question of why they could or would not regularize their status by conversion and marriage. Was there a possibility to cross the boundaries of their respective religions? Only during the police investigation did Filippo express his wish to become a Muslim and marry Sitêta. One cannot get away from the impression that he did so only under the pressure of the circumstances, hoping for leniency on the part of the councilors. Why had he not done this earlier? A person's religion was, in nineteenth-century Egypt, as in many other times and periods, more than a matter of personal conviction and belief. Having a religion had legal consequences and also social effects. For Filippo, the social consequences must have weighed heavily. By conversion to Islam he would have been expelled from his community. It is plausible that his business network was mainly located within his own community. Therefore, conversion to Islam, while enabling him to marry Sitêta and at the same time solving the problem of his being married - if he was -, would also have entailed the ruin of his business. Therefore, it is not difficult to imagine his hesitance to do so. For Sitêta, a change of religion would have been out of the question as it would not have solved the problem. A Muslim who renounces his faith loses his or her legal capacity and enters a state of what may be compared to mort civile (legal, but not physical dead). That means that even if she had expressly adopted Christianity, she would not have been able to contract a marriage with Filippo in Egypt. In addition, there is the aspect of criminal law. I have no information on the question of how apostasy was punished in this period in Egypt, but it is not unlikely that Sitêta would have faced imprisonment. However, at least as serious are the social consequences : the apostate as a rule is repudiated by his family and his social environment.

Égypte/Monde arabe, 34 | 1998 

family and injured her honor by having deflowered her. The Police Council quoted Sections Two (injuring a person's honor) and Six (abduction of a girl) of Chapter Two of the Imperial Code. The latter Section, however, was not mentioned by the Cairo Council and the majlis al-ahkâm, no doubt because the councilors felt that inciting a girl to leave her parents cannot be put on a par with abduction, especially since the girl came to Cairo of her own accord. The Cairo Council and the majlis al-ahkâm added Section One of Chapter Two as extra grounds for the sentence. It is not immediately clear why they should have done so, since the Section deals with the same offense as Section Two. The only plausible reason is that Section One, although it only mentions punishment according to the shari'a, to some extent specifies the notion of injuring a person's honor to which Section Two refers with the words "a case of this nature." However, in neither Section are unlawful sexual relations expressly mentioned. The wording of these Sections shows that the level of the legislative technique used in drafting the law was not very advanced. Actually, Section Two does not even specify the punishment. It simply repeats provisions from Islamic law textbooks with regard to ta'zirpunishment. The low level of juridical sophistication is also apparent in the way the law was applied. The councilors had not been trained as lawyers and this is often evident in the way they handled the laws. The reason for this absence of juridical skills is that no law schools existed, apart from the religious institutions where Islamic jurisprudence was taught.

It is striking that the difference of religion is not explicitly referred to in the records of the trial. In introducing the characters, the religious status of Filippo is mentioned. He is called a dhimmî which, under Islamic law, defined his legal status, being a rûmî (Greek Orthodox) and a subject of the Ottoman Empire. However, when the councils specified the offenses committed by the couple, this aspect remains in the background. It was discussed only indirectly when the Police Council considered his conversion and decided that it came too late and therefore could not prevent his conviction (hukm siyâsî). This implies that the difference in religion certainly played a role as an aggravating circumstance. However, this is difficult to prove without further systematic archival research in order to examine the sentences for these offenses. The sentences for illegal sexual relations that I have seen vary between caning and six months of detention for the man, whereas no mention is made of the woman's punishment. The sentences of one year hard labor for Filippo and one year in the women's prison for Sitêta seem quite harsh in this light. This can only be explained by the circumstance that Filippo was a Christian and Sitêta a Muslim.

\section{Conclusion}

In this essay, I presented a criminal case tried in Egypt in the early 1860s. I attempted firstly to make the case understandable by situating it in its legal, social and historical context and secondly to examine how the state authorities at that time dealt with persons from juridically defined non-dominant groups who transgressed the rules that reinforced their marginality. The case selected here centered around sexual relations that were doubly forbidden : first, because they took place outside of a lawful marriage and second, because they could not simply be regularized, due to the existence of a religious obstacle. From the trial it became clear that the presence of this religious obstacle did not constitute an offense in itself-rather, the unlawful sexual relations

Égypte/Monde arabe, 34 | 1998 
and the circumstance that the girl had left her family were the central grounds for the sentence. However, there are strong indications that the religious impediment, in spite of the man's conversion to Islam during the police investigation, was regarded as an aggravating circumstance.

\section{BIBLIOGRAPHIE}

Baer, G., 1969, « Tanzimat in Egypt : the Penal Code, » in : G., Baer, Studies in the Social History of Modern Egypt, Chicago : University of Chicago Press.

Jallâd, F., 1890-95, Qâmds al-idâra wa-l-qadâ', 5 vols, Alexandria : al-Matba'a al-bukhâriyya.

Peters, R., 1997, Islamic and Secular Criminal Law in 19 th-century Egypt : the Role and Function of the Qâdî, » Islamic Law and Society 4/4 :70-90.

Skovgaard-Petersen, J., 1997, Defining Islam for the Egyptian State: Muftis and Fatwas of the Dâr allftâ', Leiden : Brill.

Zaghlûl, A. R, 1900, al-Muhâmât, Cairo : Matba'at al-ma'ârif.

\section{ANNEXES}

\section{Appendix : The text of the pertinent Sections of the Imperial Code}

\section{Chapter Two}

(Section One) Whereas all subjects of the Ottoman Empire have acquired lawful rights consisting of safety of life and property and protection of one's honor and good name, and whereas consequently they can claim their rights, regardless of their status, in accordance with freedom as circumscribed by the law, and not in accordance with absolute freedom, and whereas a person's honor and good name is as dear and respected to him as his own soul, and whereas the safeguarding and protecting of honor is required by virtue and humanity, and whereas slander (al-qadhf bi-lkalâm)violates a person's respect and prestige and beating or abusing him without good reason is regarded as an injury to one's honor and an assault on his respect, it is therefore necessary that anyone against whom it has been proven, according to the shari'a, that he has had the audacity to injure a person's honor in a manner that makes the application of the haddpunishment obligatory, shall be punished with the haddpunishment according to the shari'a.

(Section Two) If a case of this nature [injuring a person's honor, mentioned in the previous section] is committed in Cairo and if it must be punished only with ta'zîr, then the defendant's situation and social position must be examined since the ways and 
manners of fa'zîr vary according to these factors. If the person to be punished by ta'zîr isan important religious dignitary (min al-'ulamâ' al-fikhâm wa-l-sâdât al-kirâm), a prominent personality, or a high-ranking official, he shall be summoned to the majlis alahkam and receive a proper punishment. If he belongs to the middle classes (awsât alnâs) or common people (al-sûqa) and their likes, he shall be brought before the Council and be punished with imprisonment or banishment, according to the circumstances. If he belongs to the lowest classes (âhâd al-nâs), he shall be disciplined by imprisonment, banishment or a beating consisting of three to seventy-nine strokes according to the shari'a. Outside Cairo, these cases shall be dealt with in the same way by the provincial governor (mudîr al-mahall). People shall not be convicted for these offenses on the strength of complaints only and there must take place careful examination to find evidence and if the complainant is proven to have lied, he shall be punished with five to forty-five days detention.

(Section Six) If someone has the audacity to commit unacceptable acts such as abducting Muslim or non-Muslim girls to another region or another country claiming that he has married her without her relatives knowing it, then he must be arrested and his case must be investigated by the governor of the region. Then he and the dossier of his case shall be sent to the Regional Council for trial. If his offense is proven, he shall be punished according to what the Council sees legally fit, with six months [detention] to chastise him. (...)

\section{Chapter Five}

(Section Seven) If an official in government service, regardless of whether he is of high or low rank, does not obey the contents of the enacted laws, or an order of the wâlior one of his superiors, his case must be investigated. If it appears that his disobedience did not result in damage to the service, he shall be punished by detention in the bureau of the directorate [of his department] for a period of ten days to one month in accordance with his circumstances. If it has resulted in damage to the service, he shall be detained in the same place for a period of one to six months in accordance with the extent of the damage. If this occurs a second time and results in damage, he shall be removed from the service and not be employed again in any government position until he regrets it and shows sincere repentance.

\section{NOTES}

1. Text in Ahmad Fathî Zaghlûl (1900, appendix : 156-178) and Fîlîb Jallâd (1890-95, II : 90-102).

2. For the political aspects and the negotiations, see Gabriel Baer (1969:109-33).

3. Baer suggests that the new code was not introduced until 1854 (Baer, 1969: 119). However, archival material indicates that it was already applied in 1852.

4. For the fatwâ and the ensuing discussion, see Skovgaard-Petersen (1997 : 319-335).

5. The presentation of the case is based on the sentence of the majlis al-ahkâm, to be found in the Egyptian National Archives (dâr al-wathâ'iq al-qawmiyya) : sîn/7/10(majlis al-ahkâm, al-madâbit al-sâdira, sijill 24 (14 dhû alhijja 1280/4 rabî'l 1281), p. 53, no. 986,7 muharram 1281.

6. The sentence of the Cairo Council was sent to the majlis al-ahkâm on 27 shawwâl 1280/5 April 1864. This means that the case was tried by the Council a few days before.

7. For the role of the qâdî in criminal justice, see Peters (1997). 
INDEX

Mots-clés : droit, Grecs, sociologie, XIXe siècle

\section{AUTEUR}

\section{RUDOLPH PETERS}

University of Amsterdam 